\title{
Coupled-Bunch Instabilities in the APS Ring*
}

\section{Finter:}

Argonne National Labontory gion So. Cass Ave., Argonne, G9.139

\section{Abstract}

A stuly of conpled bunci instabilities for the APS storage ring is presented. The instabilities are dniven by the highter-order modes of the fifteen $352-\mathrm{MH} \mathrm{Hz}$ single-ce!l $\mathrm{lF}$ cavilins. These modes are modeled using the 2-D carity program IRMFL[1]. The program ZAP[2] is then used to estimate the growti: time of the instabilities for an exually-spaced bunch jnllem. The cavily modes must responsible for the instabilities will be singlet owt for dauping.

\section{InTHOdic:TION}

One of the eventual goals of the Arlvancel Photon Sonrce (APS) main ring is the capabilicy to store 3 igl nut in many butuclies:[3]. It is therefoce valuable to intestigate the current limits imposed by conpled-bunch molion instabilities which may jeoparalize this goal. Instabilities of bunch molion in the longitudinal or transverse plane may occur when slowly decaying wakeficlis gencrated by a bunch passing throngh vacuum chanlher discontinnities are felt by following bunches. Normally. the higher-ordier modes (IIOM's) of RF carities are the largest contributurs of slowly decaying wakefields and. therefore. of couplet-bunch instabilities. The wakefictls produced in cavilies ure nsualy! described as hight- $Q$ resonator inpedauces for mach IIOM. The design of the APS carities can be found in refrence [3].

Compuler calculations of the HON inpedances of the main ting single-cell RF cavity are presented. Then the current limit due to the impedances of the fifteen RF carities is estimated. The results give a clear indication that cures against the ittstabilities are reguireal for the operation of the ring. One cure is to altach tuned datupers to the cavity in order to reduce the slunt inpclance of the strongest llOM's. To assist the (ampers. one may implement systematic geometry differences (slight elsungation of the cavities) in all or gronps of cavities to spread the HOM resonanl. freciuencies arross a mumber of revolution harmonics. This reduces the cliance that many cavity HOM's contribnte to the same coupled-bunch mode instability. The required deQing effect of the tumed dampers is estimated.

\section{CAVTYY IMIPEDANCES}

In order to predict the longitudinal and transserse coupledbunch instability limits. one would ideally nake impedance measurements on all carities to be installet in the ring. Since the carities are not built yet. one can model the monopole and dipole carily" modes using URMEL,[1], which uses a rectangular gritl on the sadial-longitndinal plane. An ont pun file provides the resonant freguency $f_{r}$, the shunt inpedance $R_{s}$ and the ynulity factor $Q$ for each HOM. Taliles 2 and 3 list the strongest modes liclow the cut-of fiennenry of the carity beampipe.

Since the rectangular grid can't fit the splierical contonr of the carity exactly and since the real cavity is not cylindrically symuetric dlue to the $\mathrm{RF}$ power conpting loop and various

- llink supposted by (I.S. Depmantment of Energs, Olice of Basic Encrgy Sujeuces useler Conl sact No. W-31-10n-ENCi-39.
Talle 1

longitulinal conplenl humelmotion with one carily.

\begin{tabular}{|c|c|c|c|c|}
\hline $\begin{array}{c}f_{\mathrm{HOM}} \\
{[\mathrm{MH} \mathrm{Hz}]}\end{array}$ & $\begin{array}{c}R \\
\text { (MIn) }\end{array}$ & $Q$ & $\begin{array}{l}1 / \mathrm{rosm} 2 \\
\left(\mathrm{sec}^{-1}\right)\end{array}$ & 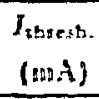 \\
\hline 536.7 & $1.6 \pi$ & 410010 & 7 & 80. \\
\hline $92 \geq 2.5$ & 0.62 & 1061100 & 5018. & 1:36. \\
\hline צ39.0 & 0.23 & reono & $\mathbb{1} \leqslant 1\}$ & 340. \\
\hline 1153.2 & 0.13 & 41018 & 190 & 3411. \\
\hline 1210.5 & $0.4 ?$ & $94(1)] 0$ & 510. & 1311. \\
\hline I5150.. & 0.40 & $s$ ssund & $511 \%$. & 130. \\
\hline
\end{tabular}

Talbe 2

Transverse compled humeh molion with one eavity.

\begin{tabular}{|c|c|c|c|c|}
\hline $\begin{array}{c}f_{\mathrm{HOM}} \\
\text { (MIllz) }\end{array}$ & $\begin{array}{c}R_{s} \\
(M / \Omega / m)\end{array}$ & $Q$ & $\begin{array}{l}1 / \mathrm{r}_{200 \mathrm{~m}-1} \\
\left(\mathrm{sec}^{-1}\right)\end{array}$ & $\begin{array}{l}I_{\text {shrest }} \\
(m \Lambda) \\
\end{array}$ \\
\hline $588 . \overline{1}$ & 13.5 & gsomon & 348. & S11. \\
\hline$\overline{561.1}$ & 25.6 & 53000 & (3). & 43. \\
\hline 962.0 & 6.1 & 5.1000 & 1iil. & \$\$1). \\
\hline 1017.4 & 2.6 & Iluou & 73. & 43. \\
\hline 1145.1 & 2.7 & 92000 & 78 & fl11. \\
\hline 1211.2 & 3.6 & - 1 (10) & Ji1. & 315 \\
\hline
\end{tabular}

ports). One would expect the measured frecguenciss of an assembled cavity to differ from the UIRALL calculation. 'The measured frcyucucies of a protoly pe cavily are reportal in [-1]. The URNEL [requencies should therelore be taken as uncerthin to some extent. For conservative eslimates of the conplatbutch instability grourth rates, the frequencies will be sliff rol to the closest posilive revolution freynency larmonic synchirul ron sillebantl.

In acldition. the $Q$ of each IIOM may he lower in the real cavity due to the influence of the Rf power coupling loop. It is expected howescr that the measured salue of $R, / Q$ should not clange appreciably from the calculated one.

This paper will include only llOM's will frequeury lower than the cut-of freguency for the $i-c m$ radius beam jipe connecting the RF cavities. However. standing wave motles can be trapped in these sections. The TM mole cutort Irexpucury for $\bar{i}$-cm ratins is $3.6 \mathrm{GHJz}$ while the cutoff frespency for the regular elliphical racuum chanther is 4.5 cillz. All moles of in-

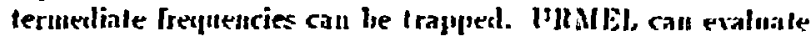
the imperdance coul ribuled by these. and they are by no means negligille.

Alssorliug materials placed in these regiens will damp these motes. I will assume that strong damping is murl more basily. arlicived for these modes than for the lower llOM's. and ino further stuly is required for the moment.

\section{Ring Panarietens}

Talyle 1 lists the relevant ring parameters for the statility 


\section{DISCLAIMER}

This report was prepared as an account of work sponsored by an agency of the United States Government. Neither the Utited States Government nor any agency thereof, nor any of their employees, makes any wassanty, express or implied, or assumes any legal liability or responsibility for the accuracy, completeness, or usefulness of any information, apparatus, product, or process disclosed, or represents that its use would not infringe privately owned rights. Reference herein to any specific commercial product, process, or service by trade name, trademark, manufacturer, or otherwise does not necessarily constitute or imply its endorsement, recommendation, or favoring by the United States Government or any agency thereof. The views and opinions of authors expressed herein do not necessarily state or reflect those of the United States Government or any agency thereor. 
calculations. The bunch length used in the calculations takes

Tallo:3

Paramulers used in Stability ralrulations

\begin{tabular}{|c|c|}
\hline Encrgr $E$ & i Liel \\
\hline Revolution frequency $f_{0}$ & $271.55 \mathrm{kilz}$ \\
\hline liF frequency /aF & $351.931 \mathrm{M} / 12$ \\
\hline RF llarmonic number $h$ & $1: 296$ \\
\hline R.F voltage linF & $9.5 \mathrm{NH}^{\circ}$ \\
\hline Satural Bunch length $\sigma_{0}$ & $5.33 \mathrm{111 \textrm {m }}$ \\
\hline Bunch lenglh $\sigma_{l}$ & $7.0 \mathrm{~mm}$ \\
\hline Energy Spread $\sigma_{c}$ & $9.6 \times 10^{-4}$ \\
\hline Nomenlum compaction $\eta$ & $2.2 s \times 10^{-4}$ \\
\hline Spmehrotron frepuenes $f:$ & $1.19 \mathrm{kIIz}$ \\
\hline Synchrotron tune $v_{\text {s }}$ & 0.110 .519 \\
\hline Worizontal tune ps & 35.2 \\
\hline Vertical inne $n_{3}$ & 1.1 .3 \\
\hline Longitudinal damping rate $1 / r_{6}$ & $213 \sec ^{-1}$ \\
\hline Longit nelinal damping line $r_{e}$ & A.i uiser \\
\hline 'Transverse danuping rale $1 / \tau_{e}$ & $106 \sec ^{-1}$ \\
\hline Trancverse daumping time $\tau_{c}$ & $9.4 \mathrm{insec}$ \\
\hline Total current I & $300 \mathrm{nit}$ \\
\hline Nimuler of humclies $n_{b}$ & 5.1 \\
\hline Bunch curreut $I_{b}$ & $5.6 \mathrm{m.t}$ \\
\hline
\end{tabular}

inlo arconnt single bunch intensity efferls for a bunch current of $;$ mit according to a pseuto-Green [utction method[5]. The ellerg: spreasl is not allecled however. Since $5 \mathrm{mI}$ is close 10 the Iransverse mule coupling limit[5]. the number of lmnches for a tutal curtent of $300 \mathrm{~mA}$ is set. at $5 \cdot 1$. which must be a factor of $h$ for the apjlication of most calculational met liods of growth rates of conpled-bunch instabilities.

\section{Coupled-Buncil Mlodes Growta Rate}

The threshold current for instabilities in electron storage sings is deternined ly the partially cancelting aclion of instability growth and the sychchrotron ratiation damping rate. The instability gromih is proportional to the stored current. while the radiation dam! ing rale is constant. 'Jise current threshohl is then dofined as the cursent at which the instahility growth is ecunal to the damping cale. All growyth mites will be caloulaled for $J=3 m \mathrm{~mA}$. The current threshold will be extrapolated from

$$
I_{\text {lureeh }}=30 \text { lhuld }\left(\frac{T_{c}}{T_{30001}}\right) \text {. }
$$

The conplad-bunch modes treated in this secrion are those producel by a siamuctric bunch pallern. i.e. bunches that are chnally spacel and exually charged so that the trasme of reterence of one bunch is equivalcut to that of another. The conpled-bunch motes are then rather simple. The amplitude of all bunches is the same, and the ploase separalion of the molion of each succesive bunch is $\Delta \phi=2 \pi \mathrm{m} / \mathrm{n}_{b}$ where $n_{b}$ is the mimher of butues ( $u_{1}$ must be a factor of lhe RF harmonic number and $m$ is the couplud-bunch molte unuber where where $0<m<n_{b}-1$.
For the longituliual plane the growith ate of pach lungit ondinal mode $m$ is dcternitued by the valnes of all fongitulinal impedances sampled at revolution harmonic symchrol ron sidtr. bauds

$$
f_{a}=\left(p m_{b}+m\right) f_{0}+a f
$$

where $p$ is an integer. $f$, is the sychrot ron frcunamer. $n$ is lhe sychrotron mode unmier (for dipole mode. $a=1$ ). fo is then revolntion frequency. For a couservative estimate of the cursuat

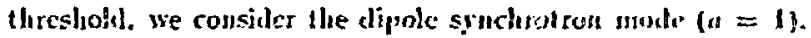
since highei nrder syuchrotron modes grow more slowly:

'The positive revolntion harmonic sillelmals $\{p>b) \mathrm{con}$ tribute to grom(h. and the negative ones $(p<$ in) contrilnte to damping. It follows from this that if a Holl causes growing fur mosle $m$, then it will canse damping for the $u_{b}-m$ modk.

Similady for the transrerse molion. the re!evanl cuanlilices are lite transierse impredances from dipole IIUM's and revolntiun larmonic befatron sidchand frequencies $f_{n}=1 m_{n}+m+$ $\left.v_{1}\right) f_{0}+$ af. . The horizontal notion is consislered licte. there fure we sel $v_{1}=v_{5}$. For zero chromaticily. fle growilt tate is greatest for the rigit hunch morle. $n=$ ll. Here positive p canses dompiug aud negalive p causes growh - lhe opusosile of longitudinal motion.

\section{A. Conserculite egrimates}

If the resolmant frequency of a monomole HON laphws to equal one of the posilire $f_{r}$ 's. then llie growth of a particular Iongiludiual coupled-lunch mode is maximnl for that IIUM. The growth rate fosmula in the Wang formalism[li] oplion of $2 A P[2]$ reduces 10 aproximaldy-

$$
\frac{1}{\tau}=\frac{I f_{\text {HoNu}} P R}{2(E / C) \omega_{s}}
$$

with $F \approx 1$. and similarly for che transverse molion and dipulv HOMIs:

$$
\frac{1}{\tau}=\frac{I c F R,}{4 \pi(E / c) u_{x}}
$$

Since one cannol easily conlsol the IIOMI frequencies. nue must assune that some of the carily $110 \mathrm{Ol}$ 's will fall on such a fie"quency. The withlis of the resonances $\left(\Delta f=f_{r} / Q\right)$ are much narrower (of orter $10 \mathrm{kll} z$ f bian the spacing het ween the harmfill revalution harmonics [2ilk!lz). "I'serefore il sroull serm that thece is a only a small chance lint a HOM Irom no more than one carity will accidentally fall on or close enough to a larmonic sideluand. Talles 2 and 3 show the worsl-case growlh rate for $I=3100 \mathrm{~m} h$ dne to the strongest indivilual $110 \mathrm{M}$ "'s from a single cavily. as calculated hy ZAP or equations 3 amal 1 . I'nfortumately the lesiret 301) $\mathrm{mA}$ current is so large that the

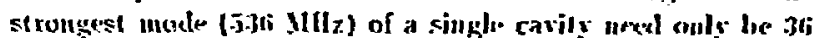

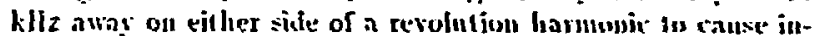

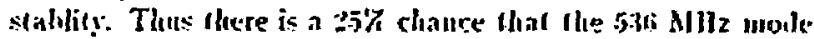
of any one carily uill canse inslability. Hith lis carilies. the growih rale for 3 un u.t will very likelv exefed the raslialion damping raie. lienlucings the shunt. impedanse is necessary.

\section{B. Sysitemolic catilies molificatioms combintil with ho Qing}

If all or sonte of the resonaut freunchcies alifur among cavilies

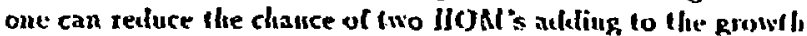

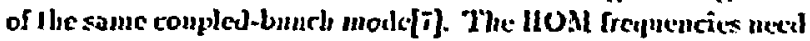
to be at lcast fo apart. The cavilies cau lie nodificd hy insenting shins befweul the center mpulurial ring of the carity and the fwo nose cone seetions. The proposed cavily elongatinn is 
along the beam axis. JRMEL was used to estimate the rate at which resonant frepuencies lecrease as a function of shim thi-kurss. Tablo 1 summanizes the results. The suantify $1 / \tau$ does not include gadiation dianging. so the salnes shown shoubl he compared to $3 / r_{\mathrm{r}}=-21.5 \mathrm{sec}^{-1}$. Convenienty: (he fondanen-

Tiable 4

Shimming the RF cavity and deQing monopole HOM:s

\begin{tabular}{|c|c|c|c|}
\hline $\begin{array}{l}\text { fHon } \\
(1) ! 2)\end{array}$ & $\begin{array}{c}d\left(f_{11 O M}\right) / d(\Delta z) \\
\left(M H_{2} / \mathrm{Mm}\right)\end{array}$ & $\begin{array}{c}1 / 5 \text { for } Q=Q_{0} / 10 \\
\left(\sec ^{-1}\right)\end{array}$ & $\begin{array}{l}\text { Reyuired } \\
\text { Q/Q }\end{array}$ \\
\hline 3.51 .93 & -0.017 & - & \\
\hline 530.7 & -0.7 & so & 4 \\
\hline $02 \cdot 3.5$ & -1.1 & 51) & 2.3 \\
\hline 139.11 & -1.1 & 19 & 1 \\
\hline 117.3 .2 & -1.3 & 19 & 1 \\
\hline 1210.8 & -2.0 & 45 & 2.1 \\
\hline 1.มีย. & -2.1 & 45 & 2.1 \\
\hline
\end{tabular}

tal mode is hardly influenced. To spreat the frequencies of the st rongest HON by a sufficient amonnt. I assume all carifies are shimmed in increasing thickness by steps of 1 mm. This sepames the $536 \mathrm{M}$ Mtz morles by ahout 2.5 fo from one cavily to the next. All the other mode [rechencies are separated by about lwire as intuch.

It would serm that the conservative aslimate of growlh rate in lie previons subsection (slown in Tables 2 and 3 ) applios exactly to this situation since no two cavities have the same HOM frequencies. Ilowever, wil 54 possibfe longitudinal modes for Dt buthes. and $15 \times(j=911$ individual $11 O M$ 's it is likely that many coupled-bunch modes will be influenced by more than one $110 \mathrm{M}$ though aliasing. i.e., $f_{\mathrm{r} 1}=\left(p_{1} n_{b}+m_{t}+\nu_{s}\right) f_{0}$ and $f_{r_{2}}=\left(p_{1} n_{b}+m+\nu_{1}\right) \int_{0}$ with $p_{1} \neq p_{2}$. But it is also likely that some HOM!'s will cancel each other in their damping and anti-damying effect on many modes. This statistical problem should be further studied. For lins reporl 1 will assume that in this fifteen carity system. there is only one HON fully exciting some conpleat-binich mode.

Inslalling dampers to lower the shunl impedance and $Q$ of individual modes car greatly reluce the gromilt rates. However. a lower $Q$ means a vider impedance function. and a larger probability that a $110 \mathrm{M}$ will contribute significanty to some coupled-bunch mode growth even if the HOM is not centered on a revolution harmonic sicteband. Table 4 lists the maximnn growlh rates for the carities with a deQing faclor of 10 . The HOM's are considered individually. The Insic result is that the growth rales are scaled by exaclly the deQing factur. Couljlet bunch modes associaled wilh adjacent sevolution harmonics (not. shown) were calculated to have a growth rate of $10 \%$ or less than those corresponding to the main excited conpled busch mode. One can specify the minimum deQing ly comparing the growth rate with the racliation dimping rate. aml one finds that the largest deQing faclor for longiludimal HOMIs is 4. These low deQing fachors may vell occur naturally due to the inpul. RF conpling loop wil hont the aid of dampers.

The transverse $110 \mathrm{~N}$ treatnent gives similar results excipt that the 588 Millz mode does not shifh appreciably with shims. This is because the electric fields of this HC: 11 lave no lougitudinal variotion. The spread of the $588 \mathrm{M} / 12$ IIOM for fifteen cavilies with $111 \mathrm{~m}$ incremental shim thickness is abont 1.2
MItz. enough to cover 5 revolution harnosirs. When dinqirs this mole oue should consider each compled-buarcin monte to he fully exciled by flutee coviliss. Tabfle s stows that the llOM

Table 5

Shinming the RF carily and d.Qing dipoln nON's

\begin{tabular}{|c|c|c|c|}
\hline $\begin{array}{l}f_{\text {HoM }} \\
\text { (MIIz) }\end{array}$ & $\begin{array}{c}\left.d\left(f_{\text {How }}\right) / d(d)=\right) \\
(\text { (Mllx/mm) }\end{array}$ & $\begin{array}{c}\left.1 / 5 \operatorname{tor} Q=Q_{0} / 10\right) \\
\left(\sec ^{-1}\right)\end{array}$ & $\begin{array}{c}\text { Rexpized } \\
Q / Q_{0} \\
\end{array}$ \\
\hline 58. & -0.08 & 117.0 & 11 \\
\hline$i 61.1$ & $-0 . i$ & i3.11 & 4 \\
\hline 962.0 & -1.2 & 17.11 & 2.3 \\
\hline 2017.t & -1.7 & 7.3 & 1 \\
\hline 1145.1 & -1.5 & 7.8 & 1 \\
\hline 121922 & -1.9 & 111. & 2.1 \\
\hline
\end{tabular}

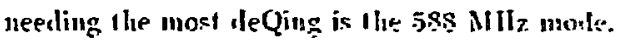

lustead of making all carilies difleron one can make gronlus of cavilies with the same shimming. However Ihis will increasc the required deQing of the modes ly a factur between I ami the number of cavities in the group. The exact droing factor depends on the stalistical distribution of freturney shift due to consl ruetion tolerances and ol her imjonderables.

\section{Coxcinsion}

The growth rale for inslabilities were evalunlal for rean-inally pessimissir cases. Thr deQuing reynirements for most of the HOM's are modest if all cavilies are shimmed dilfercmly:

\section{AChNOWLEDGENENT}

Fve greally benefilcd from couversalions will, Brumo Zolturs and Stere liraner on impedances and coupled bundi instalililies in general. 1 thank lee Teng for his gujdauce.

\section{REFEIENCES}

[1] T. Weiland N\%. rol. 216. pp. 329-3-28. 1!83.

[2] M.S. Zisuan. S. Chatiopadlyyay. and J.J. Bisognano. "ZMP Iser"s Gujde." LBL 212Tu, Lawrence Berkeley Laboratory. December 1980.

[3] APS. "i Ger Syurholron Radialion Source Conceplual Desigu leport." ANL 8T-15. Al'S. 1987.

[-1] J. Cook. J. Bridges. and R.L. Kustom. "Mleasurement on Prolotype C'avities (352 Mlliz) for the Alwanced Pholon Source (APS).- in Procidings of the IVy) JEEE Particli Accelerutor Conferemie. Jin!l.

[D] W.Chou and H. Bizet. -lonpedance and Bunch Leugthening. in the APS:- in Frocedlings of the Inpedunce and Bunch Inslubility Horkshup. 199n.

[i] J.M. Wang. "Lungitulinal stommel ric (onpled Bunch Muiles.- BNL 5130)2. BNL. December 1980.

[i] R. Linstom. Private commmnication. 